\title{
Når barn skades med de beste hensikter
}

\author{
I USA har det foregått et skifte i barnerettspraksis, rettssakkyndighet og vektlegging av faren for «foreldre- \\ fiendtlighet» i saker som gjelder barnefordeling og offentlig omsorgsovertakelse av barn. Norsk rettspraksis \\ er fortsatt preget av overdreven tiltro til sakkyndige. Ved å bedre rettssikkerheten og likeverdigheten i omsorgs- \\ tvister kan vi sikre barns utviklingsmuligheter og deres psykiske, biologiske og sosiale velferd.
}

I 1994 ga Robyn Dawes (1936-2010) ut boken House of cards, med undertittelen Psychology and psychotherapy built on myth (1). Han påviste utstrakt bruk av udokumenterte psykologiske myter i sakkyndighetsarbeid. Han var ikke bare psyko$\log$, han var også beslutningsteoretiker, med sterk intensjon om å styrke rettssikkerheten ved å stille strengere krav til vitenskapelighet i sakkyndighetsvirksomheten.

Den amerikanske psykologforeningen (American Psychological Association, APA) har videreført arbeidet Dawes påbegynte som president i foreningen. I nyutgivelsen av deres håndbok for rettspsykologi skrives det om skiftet i rettstenkningen omkring barnefordeling og barns rett til kontakt med foreldrene at man har gjennomgått et paradigmeskifte - fra blind tiltro til sakkyndighetserklæringer til kritisk undersøkelse av prosedyrer for innhenting av data og validiteten av konklusjonene i ekspertuttalelser (2).

I norsk jus og rettspsykologi er det lite som tyder på et paradigmeskifte, selv om noen har satt søkelys på de sakkyndiges uberettiget sterke stilling $i$ vår rettspleie $(3,4)$. Nordhelle peker på en uheldig kultur av overdreven tiltro til de rettssakkyndiges konklusjoner ved at dommere $\mathrm{i}$ altfor stor grad lener seg på disse, har få kritiske merknader til deres konklusjoner og tillegger kunnskap fra andre kilder liten eller ingen vekt under rettsforhandlingene. Svakhetene i rettspleien i familie- og barnevernsrettslige spørsmål var en hovedgrunn til at nær 200 fagpersoner henvendte seg til barne- og likestillingsminister Solveig Horne i juni 2015 med en «bekymringsmelding om barnevernet» (5).

\section{«Barnets beste»}

Raundalen-utvalgets innstilling hadde som målsetting å undersøke i hvilken grad «det biologiske prinsipp» hadde fătt en for sterk rettsstilling i barnevernet og i barnevernsjusen i Norge. Utvalget bekrefter en internasjonal utvikling i rettsforståelsen om barnevern med å gi prioritet til «barnets beste». De knesatte et nytt overordnet prinsipp kalt «prinsippet om utviklingsfremmende tilknytning». Selv om utvalget bekrefter at det er av verdi å vokse opp med sin biologiske familie, er denne verdien nå gjort betinget av i hvilken grad dette er utviklingsfremmende for barnet (6). Dermed blir en grunnleggende verdi omgjort til instrumentelt hensyn (7).
En ytterligere svakhet med innstillingen er at utvalget forholder seg til forskningslitteratur som viser årsakssammenhenger mellom traumatiske oppvekstvilkår og psykososiale skader, men unnlater å forholde seg til forskning der man problematiserer de diagnostiske vanskene med å kunne avsløre samspills- og tilknytningsvansker. Dermed befester utvalget en rettspraksis med sterk avhengighet av sakkyndiges usikre observasjoner og subjektive fortolkninger.

I innstillingens forskningsoppsummering er det heller ikke viet plass til forskning som påviser skadevirkninger av å frarøve barnet kontakt med sine biologiske foreldre

\section{«Vekselvis omsorg} fra mor og far etter samlivsbrudd, med delt bosted, er det

\section{beste for barnet»}

og andre omsorgspersoner etter barnevernsavgjørelser og barnefordelingsrettslige avgjørelser. I APAs håndbok er dette utførlig omtalt, ved at «parental alienation» får bred plass (2). På norsk bruker vi begrepene «foreldrefiendtlighet» og «foreldrefremmedgjøring».

I omsorgstvister der et barn tvinges til å ta avstand fra en forelder det holdes borte fra, føres barnet inn i slike fremmed- og fiendtliggjørende prosesser. Den forelderen som urettmessig holder barnet borte fra den andre og fra omsorgspersoner fra den utstøtte forelderens familie, får ikke sjelden støtte fra terapeuter, sakkyndige og myndighetspersoner (8). Ofte er støtten motivert av empatiske overdrivelser og sentimentalitet i forholdet mellom klienten på den ene side og terapeut eller myndighetsperson på den annen. Det er viktig å presisere at i noen tilfeller er den forelderen som holdes borte fra barna, en fare for både barna og den andre forelderen (9). I APAs håndbok er man tydelig på kun å bruke begrepet «parental alienation» i de tilfeller der den utstøtte omsorgspersonen har akseptable omsorgsevner (2).

«Barnets beste» er grunnleggende i norsk barnelovgivning, som det er det i FNs barne- konvensjon (art. 3) (10). Den europeiske menneskerettserklæringen garanterer barnet retten til privatliv og familieliv (art. 8) (11). Barnekonvensjonen spesifiserer hva vi skal forstå med barnets beste - å ivareta barnets behov for omsorg, kjærlighet og bekreftelse i hverdagskontakten med begge foreldre eller dem som virkeliggjør foreldrerollene. Barnet skal ikke holdes tilbake eller bortføres til andre land eller til andre områder i landet hvis dette gjør gjensidig omsorg vanskelig. Det skal ikke utsettes for fysisk eller psykisk mishandling, det skal sikres retten til familieliv og opprettholdelse av egen identitet. Barnets rett til å gi uttrykk for sine meninger med bakgrunn i saklig og korrekt informasjon er en del av rettsforståelsen. Å kreve at barnet velger den ene forelderen fremfor den andre må anses som brudd på barnets rett.

En stor metastudie bekrefter at det er til barnets beste å få kjærlighet og bekreftelse fra begge foreldre eller fra dem som er trådt inn i foreldrerollen (12). I en studie med ungdom i Sogn og Fjordane er det også vist at de som opplever å miste kontakten med den ene forelderen (gjelder nesten utelukkende fedre), rapporterer om sterk økning i depressive plager, angstsymptomer og kroppslige helseplager (13). I motsetning til hva som ofte fremholdes i det offentlige ordskiftet om barnepolitikk, er det godt forskningsbelegg for å hevde at vekselvis omsorg fra mor og far etter samlivsbrudd, med delt bosted, er det beste for barnet (14).

Hvis barnet mister kontakten med én eller begge foreldre, uten at det gjennom en saklig og upartisk utredning påvises alvorlige mangler og misforhold, er dette å anse som et grovt traumatisk overgrep. Selv om det er et faktum at barn utsettes for mishandling av biologiske foreldre, ønsker ikke den amerikanske psykologforeningen å lukke øynene for at tapt foreldrekontakt uten saklig grunn også representerer et grunnleggende og skadelig overgrep mot barn, på linje med andre former for omsorgssvikt. De sosiale og biologiske konsekvensene av slike traumer er i økende grad kartlagt i litteraturen (15) og omfatter også foreldrefiendtlighet $(16,17)$.

\section{Likeverd i samlivskonflikter}

Når én forelder monopoliserer omsorgen og knytter et barn til seg gjennom å demonisere den annen part, kan barnet utvikle fiendtlige oppfatninger av den forelderen det ikke har kontakt med. Barn er sensitive 
for slikt og kan uttrykke stereotype forestillinger om den eller dem det ikke har kontakt med. Dette er et faresignal og et uttrykk for at barnet blir misbrukt til andres formål. Slike stereotypier skiller seg fra barns avstandtaken fra foreldre som står bak alvorlig omsorgssvikt $(16,17)$. At et barn ikke utvikler empati med den ene eller begge foreldre, representerer et utviklingspsykologisk problem som senere kan forstyrre barnets evne til selvempati, sosial omgang og mellommenneskelig toleranse. Det er dette som er bakgrunnen for at Familie- og likestillingdepartementet foreslår likestilt og delt omsorg i familierettslige tvister.

Hensikten er å dempe konfliktnivået i samværs- og omsorgstvister. Vi er klar over at der er gjort endringer i saksbehandlingsreglene for barnelovsaker i domstolene som har vært positive $(3,18)$. Slike endringer følges nå opp med at regjeringen ønsker å endre barnelovens paragrafer som pålegger domstolene ved en rettssak å velge fast bosted hos én av foreldrene og gi denne større avgjørelseskompetanse i forhold som gjelder barnet. Det er liten tvil om at eksisterende lovformuleringer er en viktig begrensning i foreldrenes mulighet til å være likeverdige i samlivskonflikter. I tillegg kan det norske barnebidragssystemet, hvor det økonomiske bidraget fra samværsforelderen er avhengig av tid sammen med barnet, og Navs støtteordninger for enslige forsørgere stimulere den forelderen som barnet bor fast hos til å monopolisere kontakten med barnet (18). Det er et paradoks at på tross av en politisk målsetting om å redusere tapet av kontakt mellom barn og foreldre etter samlivsbrudd, synes tapet av foreldrekontakt å være ganske stabilt (13).

\section{Et angrep på barns velferd}

Derfor mener vi at regjeringens bestrebelser på å styrke likestillingen mellom foreldrene i omsorgstvister fremmer barns rett til omsorg fra begge. Derimot ser vi det som problematisk at politisk-ideologiske styringssignaler nedtoner retten til omsorg fra biologiske foreldre. De protester som i dag utspiller seg internasjonalt, knyttet til tvangsvedtak mot immigrantforeldre og deres barn, har som bakteppe at styringssignalene i løpet av få år har ført til tydelige holdningsforskyvninger hos de barneverns- ansatte når det gjelder vektleggingen av barnets behov for kontakt med biologiske foreldre (19).

$\mathrm{Vi}$ vil derfor fremholde at barnepolitikken i sterkere grad må vektlegge forskningsfunn om at foreldrefiendtlighet og foreldrefremmedgjøring er skadelige og utviklingstruende faktorer for barn. Samfunnets politiske, juridiske og profesjonelle institusjoner bør også kritisk revurdere om barnets rett til kontakt med sine biologiske foreldre skal reduseres fra en grunnleggende verdi til et instrumentelt hensyn underlagt profesjonelles vurderinger. Vi frykter at et slikt verdiskifte representerer et utilbørlig og autoritært angrep ikke bare mot foreldre, men også mot barns utviklingsmuligheter og psykiske, biologiske og sosiale velferd.

\section{Eivind Meland}

eivind.meland@uib.no

Lena Hellblom Sjögren

Eivind Meland (f. 1950) er fastlege i Bergen og professor i allmenn- og samfunnsmedisin ved Universitetet i Bergen. Han har hatt en langvarig interesse for fagetiske spørsmål og har ytret seg om slike likke minst i Tidsskriftets spalter) i nær 30 år.

Forfatter har fylt ut ICMJE-skjemaet og oppgir følgende interessekonflikter: Han har vært medunderskriver på en petisjon til familie- og likestillingsministeren med det formål å bedre rettssikkerheten i barnevernsrettslige spørsmål og sikre god kvalitet $\mathrm{i}$ barnevernstjenesten. Han deltar også i et nettforum, kalt Faglig barnevernsforum, med identisk målsetting.

Lena Hellblom Sjögren (f. 1948) er filosofie doktor og psykolog. Hun har vært redaktør for KRitisk UTbildningstidskrift (KRUT), forfatter og foreleser.

Forfatter har fylt ut ICMJE-skjemaet og oppgir følgende interessekonflikter: Hun har via sitt selskap Testimonia og $3 \mathrm{~V}$-förlaget arbeidet med utredningsoppdrag og gitt juridisk hjelp til foreldre i barnevernssaker i Sverige og i andre land, deriblant Norge.

\section{Litteratur}

1. Dawes RM. House of cards. Psychology and psychotherapy built on myth. New York: The Free Press, 1994

2. Ackerman MJ, Gould JW. Child custody and access. I: Cutler BL, Zapf PA, red. APA handbook of forensic psychology. Washington D.C.: American Psychological Association, 2015: 425-57.

3. Koch K. Evaluering av saksbehandlingsreglene for domstolene i saker om foreldreansvar, fast bosted og samvær. 2008. www.regjeringen.no/ no/dokumenter/evaluering-av-

saksbehandlingsreglene-for/id503721/(22.8.2016).

4. Nordhelle G. Praktisering av sakkyndighetsarbeid i barnefordelingssaker - til barnas beste? Tidsskrift for familierett, arverett og barnevernsretts lige spørsmål 2011; 3: 176-97.

5. Skogstrøm L. Fagfolk melder bekymring om barnevernet. Aftenposten 10.6.2015. www.aftenposten.no/ nyheter/iriks/Fagfolk-melder-bekymring-ombarnevernet-8052187.html (22.8.2016).

6. Norges offentlige utredninger. Bedre beskyttelse av barns utvikling - Ekspertutvalgets utredning om det biologiske prinsipp i barnevernet. NOU 2012: 5 www.regjeringen.no/no/dokumenter/nou-2012-5/ id671400/ (22.8.2016)

7. Eide SB. Barnevernets biologiske prinsipp. I: Mesel T, Leer-Salvesen P, red. Moralske borgere. Kristiansand: Portal forlag, 2016: 128-47.

8. Meland E, Thuen F. Legen som pasientens advokat-om lojalitetens grenser. Tidsskr Nor Lægeforen 2003; 123: 190-2.

9. Hooper LM, L'Abate L, Sweeney LG et al. Models of psychopathology. Generational processes and relational roles. New York: Springer Science and Business, 2014

10. Unicef. Barnekonvensjonen. www.unicef.no/ barnekonvensjonen/full-tekst (16.8.2016).

11. Lov om styrking av menneskerettighetenes stilling i norsk rett (menneskerettsloven). https://lovdata.no/dokument/NL/lov/ 1999-05-21-30/* (16.8.2016)

12. Khaleque A, Rohner RP. Transnational relations between perceived parental acceptance and personality dispositions of children and adults: a meta-analytic review. Pers Soc Psychol Rev 2012: 16: 103-15

13. Reiter SF, Hiörleifsson S, Breidablik HJ et al. Impact of divorce and loss of parental contact on health complaints among adolescents. J Public Health (Oxf) 2013; 35: 278-85

14. Turunen J. Shared Physical Custody and Children's Experience of Stress. Families and Societies Workings Paper Series 2015; 24.

15. Getz L, Kirkengen AL, Ulvestad E. Menneskets biologi - mettet med erfaring. Tidsskr Nor Legeforen 2011: 131: 683-7.

16. Miller S. Clinical reasoning and decision-making in cases of child alignment. I: Baker AJL, Sauber SR, red. Working with alienated children and their families. A clinical guidebook. New York: Routledge, 2013: 8-47.

17. Warshak R. Parental alienation: overview, management, intervention and practise tips. Journal of the Academy of Matrimonial Lawyers 2015; 28 : $181-248$.

18. Reiter SF, Kaldhol EF, Meland E. To foreldre også etter skilsmisse. Tidsskrift for familierett, arverett og barnevernsrettslige spørsmål 2014; 12: 59-70.

19. Backe-Hansen E, Havik T, Backer Grønningsæter A. Fosterhjem for barns behov. NOVA-rapport 16/ 13. Oslo: NOVA, 2016

Mottatt 7.6. 2016, første revisjon innsendt 14.8.2016, godkjent 22.8. 2016. Redaktør: Ketil Slagstad.

Publisert først på nett. 